\title{
Rehukustannusten vaikutus Suomen maidontuotannon kilpailukykyyn - vertailumaina Ruotsi, Tanska, Saksa ja Puola
}

\author{
Marjaana Peltola $^{1)}$, Matti Ylätalo ${ }^{1)}$, Sami Ovaska ${ }^{2)}$ \\ ${ }^{1)}$ Helsingin yliopisto, Taloustieteen laitos, PL 27, 00014 Helsingin yliopisto, \\ ${ }^{2)}$ MTT Taloustustkimus, Luutnantintie 13, 00410 Helsinki \\ marjaana.peltola@helsinki.fi,matti.ylatalo@helsinki.fi,sami.ovaska@mtt.fi
}

\section{Tiivistelmä}

Maidontuotannon kilpailukyky riippuu maidon sekä maidontuotannon sivutuotteiden, kuten lihan, hinnoista ja niiden tuotantokustannuksista. Maidontuotannon kannattavuuteen ja kilpailukykyyn vaikuttavat kustannusten lisäksi myös tuotteista maksetut hinnat, tuotannolle maksetut tuet ja tuottavuus.

Tutkimuksen tavoitteena oli selvittää Suomen maidontuotannon kilpailukykyä vertailemalla yhteensä seitsemää tyypillistä IFCN- (International Farm Comparison Network) maitotilaa Suomesta, Ruotsista, Tanskasta Saksasta ja Puolasta. Suomi on ollut mukana IFCN- verkostossa vuodesta 2002 lähtien. IFCN-verkostossa toimii tutkijoita yli 80 maasta ja vuonna 2009 maitotilavertailuja tehtiin 147 tyypilliselle tilalle 46 eri maasta. Verkoston keskus toimii Saksan Kielissä.

Tyypillinen maitotila tarkoittaa tilaa, joka edustaa ominaisuuksiltaan valtaosaa kyseisen alueen tiloista. Tilat on muodostettu tilastotietojen perusteella, viljelijäpaneelissa yhdessä tutkijoiden ja neuvojien kanssa käyttämällä usean alueella sijaitsevan tilan tietoja tai näiden yhdistelmänä.

Tutkimustiloilta selvitettiin maidontuotannon rehukustannukset laskemalla kotoisten rehujen tuotantokustannukset ja ostorehukustannukset sekä tarkasteltiin niihin vaikuttavia osatekijöitä. Lisäksi selvitettiin teollisten väkirehujen markkinoita ja hankintaa tutkimuksessa mukana olleiden maiden IFCN- tutkijoille lähetetyllä kyselyllä. Tilojen taloutta tarkasteltiin maataloustulon, yrittäjänvoiton ja kannattavuuskertoimen perusteella.

Tutkimusaineisto koostui tilatiedot sisältävästä IFCN-tietopankista ja -maitoraportista sekä IFCN- tutkijoille lähetetyn kyselylomakkeen tiedoista. Tutkimusmenetelmäksi valittiin tapaustutkimus, koska tavoitteena oli saada yksityiskohtaista tietoa toisiinsa rinnasteisista tapauksista.

Tutkimustulosten mukaan sekä kotoisten rehujen että ostorehujen kustannukset olivat Suomen tiloilla vertailumaita korkeammat 100 tuotettua maitokiloa (EKM) kohti laskettuna. Siten korkea rehukustannus heikensi suomalaisen maidontuotannon kilpailukykyä verrattuna tutkimuksessa mukana olleisiin maihin. Tämä vaikutti osaltaan siihen, että maidon tuotantokustannukset olivat Suomen tyypillisillä tiloilla korkeat vertailumaihin nähden. Tukien ja vertailumaita korkeamman maidon hinnan ansiosta Suomen tiloilla pystyttiin kuitenkin saavuttamaan vertailumaiden kanssa samantasoiset taloudelliset tunnusluvut.

Kyselyn tulosten perusteella valittavissa olevien väkirehujen tarjoajien määrä oli Suomen ja Ruotsin tyypillisillä tiloilla 3-4 kun taas Tanskan ja Saksan tiloilla rehuntoimittaja voitiin valita 5-6 toimittajasta. Suomessa väkirehut tilattiin tyypillisesti paikallisen maatalouskaupan kautta. Ruotsissa ja Puolassa väkirehut tilattiin osuuskuntien kautta, mutta Tanskassa ja Saksassa tilaus tehtiin suoraan tehtaalta. Suomessa, Ruotsissa ja Tanskassa myönnettiin paljousalennuksia rehutilausten eräkoon perusteella. Sitä vastoin Saksassa paljousalennukset olivat harvinaisia. Pitkäkestoiset sopimukset olivat tyypillisiä Suomessa, Tanskassa ja Saksassa. Suomessa pitkäkestoisesta sopimuksesta maksettiin yleensä hyvitystä tai tuottaja sai alennusta rehun hinnasta. Tanskassa ja Saksassa pitkäkestoisessa sopimuksessa sovittiin rehulle tietty kiinteä hinta. Tällöin tuottaja hyötyy rehun markkinahinnan noustessa, mutta vastaavasti häviää markkinahinnan laskiessa. Ruotsissa ja Puolassa ei pitkäkestoisia sopimuksia tyypillisesti ollut.

Asiasanat: kilpailukyky, maidontuotanto, tapaustutkimus 


\section{Johdanto}

Maidontuotannon kilpailukyky riippuu maidon sekä maidontuotannon sivutuotteiden, kuten lihan, hinnoista ja niiden tuotantokustannuksista (Ramanovich ja Hemme 2006, s. 275). Koska maidontuottaja ei voi juurikaan vaikuttaa tuotteiden ja panosten hintoihin, muodostuu kilpailuetu maidontuotannossa yleisemmin kustannusjohtajuuden kuin erilaistamisen kautta (Ramanovich ja Lajtos 2004, s. 19-20). Kustannusjohtajuus maidontuotannossa tarkoittaa sitä, että ne viljelijät, jotka tuottavat maitoa muita viljelijöitä alhaisemmilla kustannuksilla ovat muita tuottajia kilpailukykyisempiä. Pitkällä aikavälillä yrittäjät, joilla on korkeimmat tuotantokustannukset, lopettavat tuotannon. Globaalissa mittakaavassa tämä tarkoittaa sitä, että maidontuotanto siirtyy vähemmän kilpailukykyisiltä alueilta kilpailukykyisille alueille (Ramanovich ja Hemme 2006, s. 275).

Maidontuottajan toimintaa ohjaavat monet tekniset, taloudelliset ja hallinnolliset rajoitteet sekä kannustimet. Saavutettavissa oleva yksikkökustannus riippuu kahdesta osatekijästä, jotka ovat kunkin panoksen käyttömäärä tuotettua yksikköä kohti sekä kunkin panoksen yksikköhinta. Saavutettavissa olevaan minimikustannustasoon vaikuttavat Suomessa esimerkiksi luonnonolot, sillä tuotantoolosuhteissamme on erityisiä rajoitteita pohjoisen sijainnin, maaston pirstoutuneisuuden ja pitkien etäisyyksien vuoksi. Yksittäisen maidontuottajan näkökulmasta tuotteiden ja panosten hinnat ovat pitkälti annettuja, koska ne määräytyvät joko markkinoilla tai hallinnollisesti interventiohintojen muodossa (Sipiläinen 2006).

Pekonniemen ym. (2004) mukaan karkearehun korkea tuotantokustannus on yksi keskeisimmistä suomalaisen maidontuotannon kilpailukykyä heikentävistä tekijöistä. Tuotantokustannuksia nostavat kilpailijamaita alemmat hehtaarisadot, minkä vuoksi sama rehumäärä joudutaan korjaamaan suurelta alalta sekä lyhyt laidunkausi, rehun suurempi varastointitarve ja Keski-Eurooppaan verrattuna lyhyempi aika rehun tuottamiseen käytettävissä oleva aika.

Tämän tutkimuksen tavoitteena oli vertailla Suomen, Ruotsin, Tanskan, Saksan ja Puolan maidontuotannon kilpailukykyä tarkastelemalla maidontuotannon rehukustannuksia ja niihin vaikuttavia osatekijöitä sekä tarkastelemalla teollisten väkirehujen markkinoita ja hankintaa. Tilojen taloutta selvitettiin taloudellisten tunnuslukujen avulla.

\section{Aineisto ja menetelmät}

Tutkimuksessa tarkasteltiin yhteensä seitsemää Suomen, Ruotsin, Tanskan, Saksan ja Puolan tyypillistä maitotilaa IFCN -tietopankin ja -maitoraportin tietojen sekä kyseisten maiden IFCNtutkijoille lähetetyn kyselylomakkeen tietojen avulla. International Farm Comparison Network eli IFCN -verkosto koostuu tutkijoista, neuvojista sekä viljelijöistä ja sen keskus toimii Saksan Kielissä Christian-Albrechts- yliopiston (CAU) yhteydessä. IFCN -verkoston perusajatuksena on määritellä eri alueille niin kutsutut tyypilliset tilat, jotka edustavat huomattavaa määrää alueiden maitotiloista. Käytetyt tilatiedot olivat vuodelta 2006 ja tutkimukseen valitut tyypilliset tilat olivat:

FI-44, Päijät-Häme, 44 lehmää

FI-60, Etelä- ja Keskipohjanmaa, 60 lehmää

SE-50, Skåne, 50 lehmää

DK-100, Jyllanti, 100 lehmää
DE-55BW, Baden-Württenberg, 55 lehmää

DE-80N, Schleswig-Holsteinin, 80 lehmää

PL-50, Slask, 50 lehmää

Tyypillisten tilojen tarkastelussa käytettiin lisäksi kyselyaineistoa, johon vastaukset saatiin kunkin maan IFCN -tutkijoilta. Kyselyaineistolla kerättiin tarkennuksia tyypillisten tilojen tietopankin aineistoon siltä osin kun tietopankin aineisto oli tämän tutkimuksen kannalta puutteellista tai kaipasi tarkennuksia.

Rehukustannusten vaikutuksia Suomen maidontuotannon kilpailukykyyn tarkasteltiin tapaustutkimusmenetelmällä. Menetelmä valittiin, koska tarkoituksena oli saada yksityiskohtaista tietoa muutamasta toisiinsa rinnasteisista tapauksista. Tapaustutkimuksella pyritään yleensä pikemminkin lisäämään ymmärrystä tutkittavasta ilmiöstä kuin tuottamaan yleistettävää tietoa. Keskittymällä yhden tai enintään muutaman tapauksen tutkimiseen voidaan tutkimuksen kohdetta ymmärtää syvällisemmin ja ottaa huomioon myös tapauksen luonnollinen ympäristö. Tapaustutkimuksen aineisto voi olla sekä laadullista että määrällistä ja niiden käyttösuhde voi vaihdella tutkimuksesta toiseen (Gummesson 1991, s. 76; Yin 1994, s. 90-99). 
Tyypillisten tilojen tuotantotoimintaa ja taloudellisia tuloksia tarkasteltiin Exceltaulukkolaskentaohjelmassa toimivalla TIPI-CAL (Technology Impact and Policy Impact Calculations) -laskentamallin avulla. Lähtötietoina mallissa käytetään tyypillisiltä tiloilta kerättyjä yksityiskohtaisia tilatietoja. Niiden avulla voidaan mallintaa tyypillisten maitotilojen tuotantoa ja taloutta. Koska lähtötiedot kerätään eri maista ja erikokoisilta tiloilta saman periaatteen mukaan, voidaan mallin avulla vertailla eri maiden erikokoisia tyypillisiä maidontuotantotiloja.

Kotoisten rehujen tuotantokustannus laskettiin kohdistamalla tilan kustannuksista rehuntuotannolle kuuluva osuus. Rehuntuotannon muuttuvat kustannukset saatiin suoraan tilatiedoista. Koneista ja kalustosta rehuntuotannon osuus laskettiin traktoreista sekä rehuntuotannon koneista. Rakennuksista huomioitiin rehuntuotannon osuus konehalleista ja rehuvarastot. Koko tilaa koskevat yleiskustannukset jaettiin maidontuotannolle ja kasvintuotannolle niiden kokonaistuottojen suhteessa, minkä jälkeen kohdistettiin kasvintuotannon yleiskustannuksista rehuntuotannon osuus. Työkustannus laskettiin käyttämällä ProAgria Keskusten Laaja Matu- laskelmaa sekä Lohkotietopankkia, josta saatiin koko tilan työmäärän jakosuhde rehuntuotannon ja maidontuotannon välillä. Muiden vertailumaiden työmäärä saatiin selville IFCN-tutkijoille lähetetyllä kyselyllä. Pellon kustannuksena käytettiin laskennallista pellon vuokrahintaan, joka saatiin suoraan tilatiedoista.

\section{Tulokset ja tulosten tarkastelu}

Kun kaikki kotoisten rehujen tuotannosta aiheutuneet kustannukset jaettiin tyypilliset tilan tuottamalla maitomäärällä, saatiin kotoisten rehujen kustannus sataa maitokiloa (EKM) kohti. Kotoisten rehujen kustannus 100 maitokiloa (EKM) on esitetty kuviossa 1. Puolan 50 lehmän tyypillisen tilan tilatietojen perusteella ei voitu määrittää koneiden ja kaluston sekä rakennusten poisto- ja korkokustannusta, joten ne eivät ole mukana kuviossa 1.

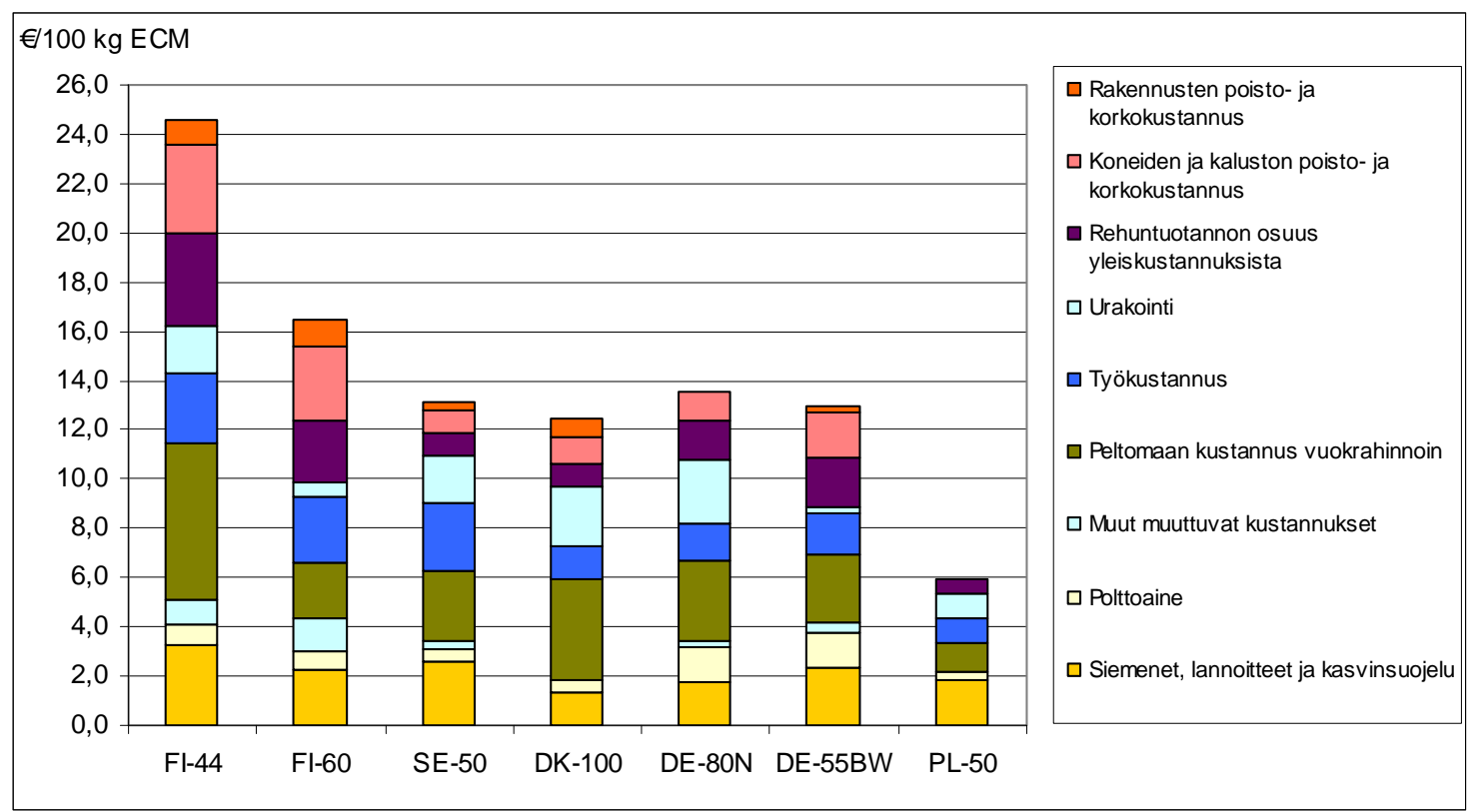

Kuvio 1. Kotoisten rehujen tuotantokustannus, €/100 kg maitoa (EKM).

Tyypillisten tilojen ostorehukustannus saatiin kunkin tyypillisen tilan tilatiedoista laskemalla yhteen tilan ostamien eri rehujen kokonaiskustannus. Tyypillisten tilojen ostorehukustannus 100 maitokiloa (EKM) kohti on esitetty kuviossa 2 tilatietojen jaottelun mukaisesti. Kuvion tarkastelussa on kuitenkin huomattava, että samalla nimikkeellä olevat rehut voivat olla koostumukseltaan hyvinkin erilaisia. Kuviossa väkirehujen kustannus sisältää myös ostetun viljan kustannuksen. Sitä vastoin oman lehmien ruokintaan käytetyn viljan kustannus sisältyy kuviossa 1. esitettyyn kotoisten rehujen tuotantokustannukseen. 


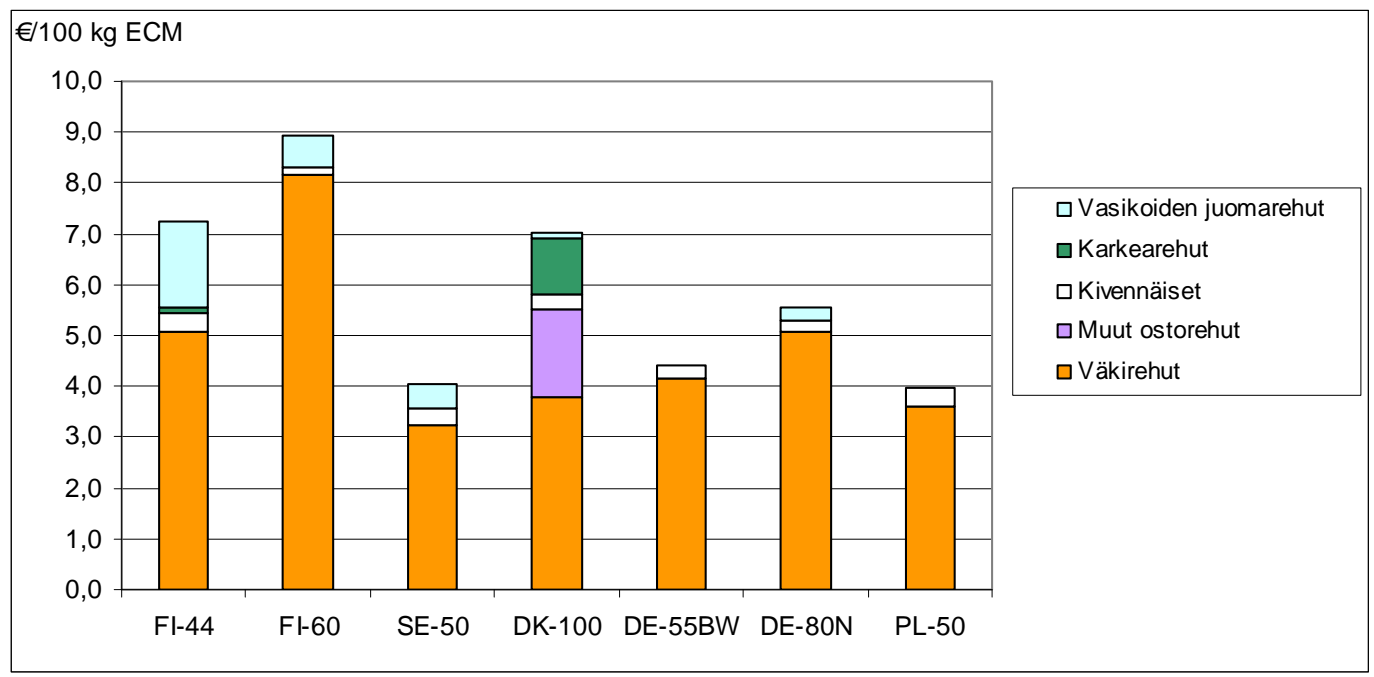

Kuvio 2. Ostorehukustannus tyypillisillä tiloilla €/100 kg EKM.

Kuviossa 3 on esitetty tyypillisten tilojen rehukustannukset ja maidontuotannon muut kustannukset. Muut kustannukset sisältävät muun kuin rehujen osuuden maidontuotannon kassamenoista, poistoista sekä oman työn palkkavaatimuksesta ja oman pääoman korkovaatimuksesta.

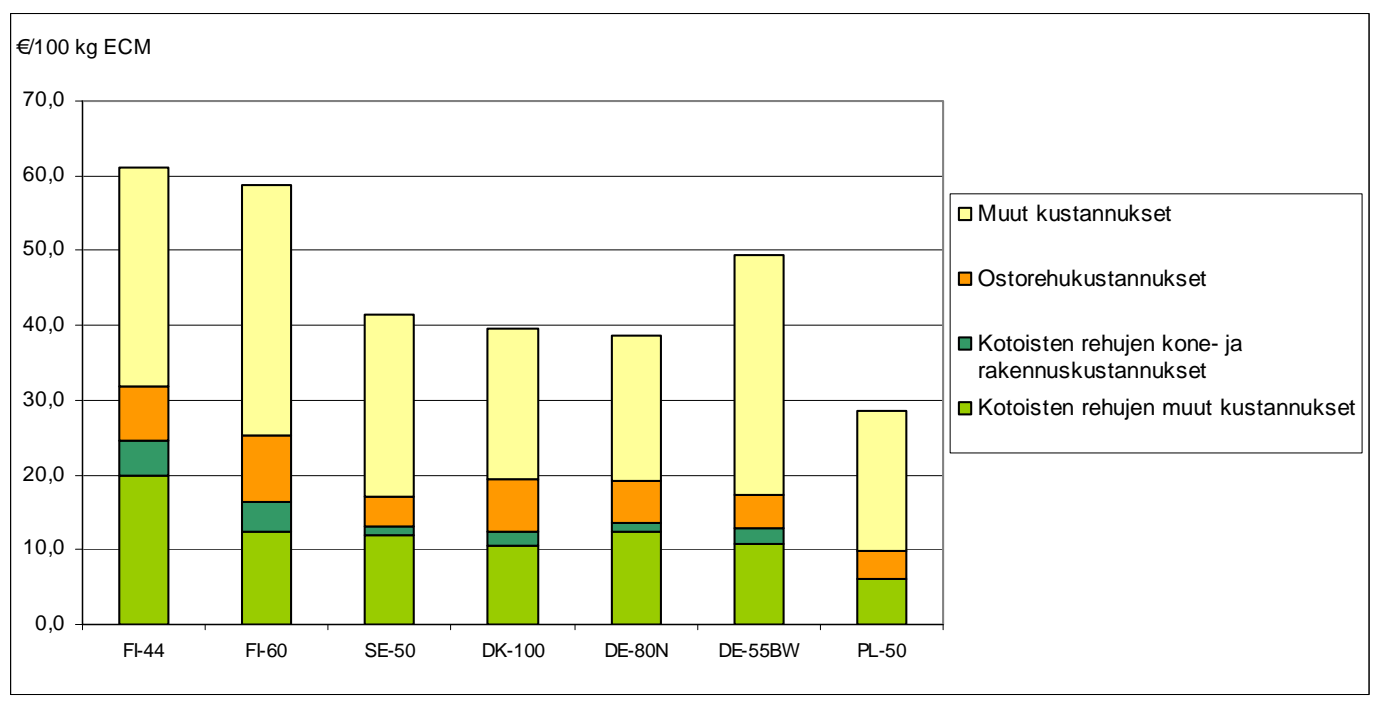

Kuvio 3. Kokonaiskustannukset tyypillisillä tiloilla, €/100 kg maitoa (EKM).

Kuviosta 3 nähdään, että rehukustannus muodostaa tiloilla merkittävän osan maidon tuotantokustannuksesta. Suomen 44 lehmän tilalla rehukustannusten osuus maidon tuotantokustannuksesta oli yli $50 \%$ ja Saksan 80 lehmän sekä Tanskan 100 lehmän tiloilla lähes $50 \%$. Suomen 60 lehmän ja Ruotsin 50 lehmän tiloilla rehukustannukset muodostivat yli $40 \%$ tuotantokustannuksesta. Saksan 55 lehmän tilalla rehukustannus oli noin $35 \%$. Puolan 50 lehmän tilalla rehukustannus ilman koneiden- ja kaluston sekä rakennusten korko- ja poistokustannuksia muodosti $35 \%$ maidon tuotantokustannuksesta.

Tutkimuksessa mukana olevien maiden IFCN-tutkijoille lähetetyssä kyselyssä selvitettiin teollisten väkirehujen markkinoita ja tyypillistä hankintatapaa. Vertailussa olivat mukana Suomen 60 lehmän, Ruotsin 50 lehmän, Tanskan 100 lehmän, Saksan 80 lehmän ja Puolan 50 lehmän tyypilliset tilat. Kyselyssä eri maiden tutkijoita pyydettiin tarkastelemaan markkinatilannetta vuoden 2008 alussa.

Valittavissa olevien väkirehujen tarjoajien määrä oli Suomen ja Ruotsin tyypillisillä tiloilla 3-4 ja Tanskan ja Saksan tiloilla rehuntoimittaja voitiin valita 5-6 toimittajasta. Väkirehujen hankintakanavat poikkesivat toisistaan siinä, että Suomessa väkirehut tilataan tyypillisesti paikallisen maatalo- 
uskaupan kautta, Ruotsissa ja Puolassa osuuskuntien kautta ja Tanskassa ja Saksassa väkirehut tilataan suoraan tehtaalta. Väkirehujen toimitusetäisyys vaihteli Suomen, Ruotsin, Tanskan ja Saksan tyypillisillä tiloilla 50-200 km välillä. Sitä vastoin Puolan 50 lehmän tyypillisellä tilalla väkirehujen toimitusetäisyys tehtaalta tilalle oli $15-20 \mathrm{~km}$.

Suomessa, Ruotsissa ja Tanskassa myönnetään paljousalennuksia rehutilausten eräkoon perusteella. Sitä vastoin Saksassa paljousalennukset ovat harvinaisia. Tanskassa paljousalennus voi olla tilatun eräkoon mukaan 3-6 \%, kun tilataan yli 6 tn väkirehua. Ruotsissa alennus voi olla 4-8 \% verrattuna alle 6 tn rehuerän yksikköhintaan, ja Suomi alennus voi olla 2-5\% verrattuna alle 9 tn rehuerän yksikköhintaan. Pitkäkestoiset sopimukset ovat tyypillisiä Suomessa, Tanskassa ja Saksassa. Suomessa pitkäkestoisesta sopimuksesta maksetaan yleensä hyvitystä tai tuottaja saa alennusta rehun hinnasta. Tanskassa ja Saksassa pitkäkestoisessa sopimuksessa sovitaan rehulle tietty kiinteä hinta, jolloin tuottaja hyötyy, mikäli rehun hinta nousee ja vastaavasti tuottaja maksaa markkinahintaa korkeampaa hintaa, mikäli rehun hinta laskee. Ruotsissa ja Puolassa ei pitkäkestoisia sopimuksia tyypillisesti ole.

Taulukko 1. Tyypillisten tilojen taloudelliset tunnusluvut

\begin{tabular}{|c|c|c|c|c|c|c|c|}
\hline EUR/100 kg maito (EKM) & FI-44 & FI-60 & SE-50 & DK-100 & DE-55BW & DE-80N & PL-50 \\
\hline Maitotuotot & 35,1 & 36,1 & 28,9 & 28,0 & 28,1 & 28,4 & 26,8 \\
\hline Muut kotieläintuotot + muut tuotot & 2,2 & 2,5 & 3,8 & 3,3 & 8,1 & 4,7 & 2,9 \\
\hline Tuotantoon sidotut suorat tuet & 8,8 & 11,7 & 2,7 & 0,1 & 2,0 & 0,3 & 0,0 \\
\hline Tuotannosta irrotetut suorat tuet & 10,2 & 8,5 & 2,4 & 4,5 & 5,1 & 5,5 & 1,4 \\
\hline Tuotot yhteensä & 56,4 & 58,8 & 37,8 & 35,8 & 43,4 & 38,9 & 31,1 \\
\hline Vuotuiset maidontuotannon kassamenot & 34,3 & 32,2 & 22,3 & 27,5 & 27,0 & 23,4 & 18,3 \\
\hline Poisto & 6,0 & 7,4 & 3,9 & 3,8 & 5,8 & 2,9 & 4,7 \\
\hline Oman työn ja pääoman kustannus & 20,7 & 19,2 & 15,4 & 8,3 & 16,6 & 12,4 & 5,5 \\
\hline Kustannukset yhteensä & 61,0 & 58,8 & 41,5 & 39,6 & 49,4 & 38,7 & 28,5 \\
\hline Maataloustulo (ilman tukia) & $-2,9$ & $-1,0$ & 6,5 & $-0,1$ & 3,5 & 6,8 & 6,7 \\
\hline Maataloustulo (ilman tuotannosta irroitettuja suoria tukia) & 5,9 & 10,7 & 9,2 & 0,0 & 5,5 & 7,1 & 6,7 \\
\hline Maataloustulo & 16,1 & 19,2 & 11,6 & 4,5 & 10,6 & 12,6 & 8,1 \\
\hline Yrittäjän voitto (ilman tukia) & $-23,6$ & $-20,2$ & $-8,8$ & $-8,4$ & $-13,2$ & $-5,6$ & 1,2 \\
\hline Yrittäjän voitto (ilman tuotannosta irrotettuja suoria tukia) & $-14,8$ & $-8,5$ & $-6,2$ & $-8,3$ & $-11,2$ & $-5,3$ & 1,2 \\
\hline Yrittäjän voitto & $-4,6$ & $\mathbf{0 , 1}$ & $-3,7$ & $-3,8$ & $-6,0$ & $\mathbf{0 , 2}$ & 2,6 \\
\hline Kannattavuuskerroin (ilman tukia) & $-0,14$ & $-0,05$ & 0,42 & $-0,01$ & 0,21 & 0,55 & 1,22 \\
\hline Kannattavuuskerroin (ilman tuotannosta irroitettuja suoria tukia) & 0,29 & 0,56 & 0,60 & 0,01 & 0,33 & 0,58 & 1,22 \\
\hline Kannattavuuskerroin & 0,78 & 1,00 & 0,76 & 0,54 & 0,64 & 1,02 & 1,48 \\
\hline
\end{tabular}

Taulukossa 1 on esitetty tutkimuksessa mukana olleille tyypillisille tiloille lasketut taloudelliset tunnusluvut. Tunnusluvuista tiloille laskettiin maataloustulo, yrittäjänvoitto ja kannattavuuskerroin ja ne on laskettu kolmella eri vaihtoehdolla: ilman tukia, ilman tuotannosta irrotettuja tukia ja huomioimalla kaikki tilan saamat tuet. Maataloustulo kuvaa viljelijäperheen omalle työlle ja omalle pääomalle jäävää korvausta. Suomen ja Tanskan tiloilla maataloustulo jäi negatiiviseksi ilman tukia. Tämä tarkoittaa sitä, että ilman tukia tuotoilla pystyttäisiin kattamaan vuotuiset maidontuotannon kassamenot kokonaan, mutta vain osa poistoista eikä omalle työlle ja omalle pääomalle jäisi korvausta lainkaan. Tukien kanssa maataloustulo oli korkein Suomen 60 lehmän tyypillisellä tilalla $(19,2 € / 100 \mathrm{~kg}$ EKM) ja pienin Tanskan 100 lehmän tyypillisellä tilalla (4,5€/100 kg EKM).

Tukien kanssa yrittäjänvoittoa saatiin Suomen 60 lehmän tilalla $(0,01 € / 100 \mathrm{~kg}$ EKM), Saksan 80 lehmän tilalla $(0,22 € / 100 \mathrm{~kg}$ EKM) ja Puolan 50 lehmän tilalla $(2,63 € / 100 \mathrm{~kg}$ EKM). Kannattavuuskerroin sai arvon 1 tai enemmän Suomen 60, Saksan 80, ja Puolan 50 lehmän tiloilla, eli näillä tiloilla kokonaistuotot olivat yhtä suuret tai suuremmat kuin kokonaiskustannukset. Siten maataloustulolla 
pystyttiin kattamaan myös oman työn palkkavaatimus ja oman pääoman korkovaatimus. Sitä vastoin muilla tiloilla kannattavuuskerroin sai arvon alle yhden eli vaadittuja korvauksia omalle työlle ja omalle pääomalle ei saavutettu.

\section{Johtopäätökset}

Tutkimustulosten mukaan Suomessa rehukustannus tuotettua 100 maitokiloa (EKM) kohti on huomattavasti vertailumaita korkeampi. Siten korkea rehukustannus heikentää suomalaisen maidontuotannon kilpailukykyä verrattuna tutkimuksessa mukana olleisiin maihin. Tutkimustuloksista ei kuitenkaan löydy yhtä sellaista tekijää, minkä vuoksi rehukustannukset Suomessa ovat vertailumaita korkeammat, vaan tekijöitä on useita. Vertailumaita korkeammat kone- ja kalusto- sekä rakennuskustannukset selittynevät lyhyemmällä kasvukaudella, minkä vuoksi rehuja joudutaan Suomessa varastoimaan vertailumaita enemmän. Korkeaa konekapasiteettia selittää myös se, että laadullisesti hyvän rehun korjaamiseen on käytettävissä vähemmän aikaa kuin vertailumaissa. Lisäksi Suomessa saman satomäärän korjaamiseen tarvitaan enemmän pinta-alaa kuin vertailumaissa, koska satotasot ovat Suomessa muita maita alhaisemmat. Siten rehuntuotantoon käytettävän peltomaan kokonaiskustannus 100 maitokiloa kohti on Suomessa korkea. Myös ostorehukustannus on suomalaistiloilla korkeampi kuin vertailussa mukana olleissa maissa.

Karkearehujen tuotantokustannuksia laskettaessa olisi ollut mielenkiintoista tietää rehun tuotantokustannus tuotettua rehuyksikköä tai muuta rehun laadusta kertovaa yksikköä kohti. Tällöin eri tilojen ruokinnan ja rehukustannusten vertailu olisi ollut tarkempaa, sillä laskettaessa kustannuksia tuotettua maitomäärää $(\mathrm{EKM})$ kohti oletuksena on rehujen suora vaikutus tuotettuun maitomäärään. Lehmien keskituotokseen, vaikuttavat kuitenkin käytettyjen rehujen lisäksi monet muut tekijät, kuten yrittäjän osaaminen, karja-aines ja eläinten olosuhteet. Siten samoilla rehuilla, voidaan erilaisissa olosuhteissa saavuttaa erisuuruinen keskituotos. Eli mitä suurempi keskituotos tietynlaisilla rehuilla saavutetaan, sitä pienemmät rehukustannukset ovat tuotettua maitokiloa kohti.

Maidontuotannon kilpailukykykyyn eri maiden välillä liittyy oleellisesti maidon tuotantokustannuksen taso. Suomessa tuotantokustannukset ovat korkeat, jota nostavat osaltaan korkeat rehukustannukset. Tämä alentaa Suomen maitotilojen kilpailukykyä kilpailijamaihin verrattuna. Korkeiden tuotantokustannusten vuoksi tuella on Suomessa suuri merkitys maitotilojen talouden kannalta. Ilman tukia maataloustulo jäi Suomen tyypillisillä tiloilla negatiiviseksi. Tämä tarkoittaa sitä, että ilman tukia tuotoilla pystyttäisiin kattamaan kokonaan vain maidontuotannon kassamenot mutta poistot vain osittain. Lisäksi pääomaa sitoutettaisiin maidontuotantoon ilman korvausta eikä myöskään omalle työlle jäisi korvausta. Kun tuet lisättiin maidontuotannon tuottoihin, Suomen tilojen kannattavuus oli Ruotsin 50, Tanskan 100 ja Saksan 55 lehmän tilaa parempi. Toisaalta kannattavuus jäi edelleen Saksan 80 ja Puolan 50 lehmän tilaa heikommaksi.

\section{Kirjallisuus}

Gummesson, E. 1991. Qualitative methods in management research. Newbury Park: Sage, cop. 212 p. ISBN 08039-4204-4

Nousiainen, J. 2006. Ruokinnan talous ratkaisee maitotilan tuloksen. Maito ja Me 4: 32-33.

Pekonniemi, J., Karhula, T. \& Ylätalo, M. 2004. Maidontuotannon 141-tuen jatkotarpeen selvittäminen. Helsingin yliopisto. Taloustieteen laitos. Selvityksiä nro 22. Maatalouden liiketaloustiede. Helsinki: Helsingin yliopisto. 83 s. ISBN 952-10-1813-5.

Ramanowich, M. \& Hemme, T. 2006. How Competitive is Milk Production in the Central and Eastern. European Countries in Comparison to Western Europe? In: Curtiss, J., Balmann, A., Dautzenberg, K. \& Happe, K. (eds., 2006). Agriculture in the Face of Changing Markets, Institutions and Policies: Challenges and Strategies. Studies on the Agricultural and Food Sector in Central and Eastern Europe, Vol. 33, Halle: IAMO, p. 271-282.

Ramanovich, M. \& Lajtos, I. 2004. Milchproduktion und -verarbeitung in Weißrussland: Eine Analyse der Wettbewerbsfähigkeit, IAMO Discussion Paper No. 77, Halle: IAMO.

Sipiläinen, T. 2006. Suomalaisen maidontuotannon kustannustehokkuuden kehittäminen. Tutkimushankkeen rahoitushakemus MMM:lle. Helsinki. $13 \mathrm{~s}$.

Yin, R. K. 1994. Case study research design and methods. Sage Publications. Newbury Park, CA. 170 p. ISBN 0-8039-5663-0 